AGNIESZKA OGONOWSKA Ośrodek Badań nad Mediami UP w Krakowie

\title{
Edukacja medialna w kontekście cyberpsychologii: nowe perspektywy badania mediów i ich użytkowników we współczesnej cywilizacji medialnej
}

\begin{abstract}
Agnieszka Ogonowska, Edukacja medialna w kontekście cyberpsychologii: nowe perspektywy badania mediów i ich użytkowników we wspótczesnej cywilizacji medialnej [Media education in the context of cyber-psychology: new perspectives for media and user research in contemporary media civilisation]. Interdyscyplinarne Konteksty Pedagogiki Specjalnej, nr 23, Poznań 2018. Pp. 93-109. Adam Mickiewicz University Press. ISSN 2300-391X. DOI: https://doi.org/10.14746/ikps.2018.23.05

The aim of the article is to show new perspectives of research and development of media, digital and information competences in the context of knowledge and research in (cyber) psychology. It draws attention to the functions of media education in relation to civil society, the society of knowledge, and the society of communication democracy. In the modern media civilization, these competences, acquired through formal and informal education, are the basis for conscious functioning in many social roles (eg citizen, consumer) and dealing with disinformation. The last part of the article is dedicated to shaping media competences in young children (2.5-7 years old), who should develop these skills under the care of an adult. The task of educational environments is the systematic implementation of home media education that facilitates the child's functioning in the environment of traditional and new media.
\end{abstract}

KEY WORDS: media literacy, cyber psychology, media, digital and information competences 
Dynamiczny rozwój mediów cyfrowych oraz ich obecność we wszystkich kluczowych sferach życia, łącznie z medyczną, psychoterapeutyczną i edukacyjną, wymagają nowego podejścia do kształcenia kompetencji medialnych, cyfrowych i informacyjnych ${ }^{1}$. Wśród Europejskich Ram Kompetencji Cyfrowych dla Obywateli (DigComp) wyróżnia się 21, które reprezentują pięć obszarów kluczowych: informacje i analiza danych, komunikacja i współpraca, tworzenie treści cyfrowych, bezpieczeństwo oraz rozwiązywanie problemów.

Tabela 1. Kluczowe obszary kompetencji cyfrowych oraz powiązane z nimi umiejętności

\begin{tabular}{|l|l|}
\hline \multicolumn{1}{|c|}{ Obszar } & \multicolumn{1}{|c|}{ TYPY umiejętności } \\
\hline Informacje i analiza danych & $\begin{array}{l}\text { Wyszukiwanie, przeszukiwanie, filtrowanie danych } \\
\text { i informacji oraz cyfrowych treści; ocena ich warto- } \\
\text { ści oraz zarządzanie nimi }\end{array}$ \\
\hline Komunikacja i współpraca & $\begin{array}{l}\text { Interakcja poprzez cyfrowe technologie; dzielenie } \\
\text { się informacjami oraz ich wykorzystanie; obywatel- } \\
\text { skie działanie za ich pośrednictwem; współpraca, } \\
\text { posługiwanie się netykietą; zarządzanie cyfrową } \\
\text { tożsamością }\end{array}$ \\
\hline Tworzenie treści cyfrowych & $\begin{array}{l}\text { Rozwijanie treści cyfrowych; lączenie i obróbka } \\
\text { cyfrowych danych, copyrighty i licencje; progra- } \\
\text { mowanie }\end{array}$ \\
\hline Bezpieczeństwo & $\begin{array}{l}\text { Ochrona sprzętu, prywatnych danych, prywatności, } \\
\text { zdrowia i samopoczucia; środowiska }\end{array}$ \\
\hline Rozwiązywanie problemów & $\begin{array}{l}\text { Rozwiązywanie technicznych problemów; identyfi- } \\
\text { kacja potrzeb oraz technologicznych wymogów; } \\
\text { kreatywne użycie cyfrowych technologii; identyfi- } \\
\text { kacja luk w cyfrowych kompetencjach }\end{array}$ \\
\hline
\end{tabular}

Źródło: opracowano na podstawie: https://ec.europa.eu/jrc/sites/jrcsh/files/DIGCOMPFINAL-\%20UPDATED\%2002-06-2016.pdf [dostęp: 23.06.18]

${ }^{1}$ A. Ogonowska, Wspótczesna edukacja medialna: teoria i rzeczywistość, Wydawnictwo Naukowe Uniwersytetu Pedagogicznego, Kraków 2013; A. Ogonowska, Kompetencje cyfrowe we wspótczesnej cywilizacji medialnej, „Studia de Cultura” 2016, nr VIII(2), s. $14-26$. 
Nowych kontekstów dla tych badań dostarcza cyberpsychologia, nowa hybrydyczna subdyscyplina psychologii, która zajmuje się wieloaspektowym badaniem złożonych relacji człowieka z technologią${ }^{2}$. Ich efekty są widoczne zarówno w sferze behawioralnej, jak i na poziomie poznawczym czy neurobiologicznym³ ${ }^{3}$.

Tabela 2. Przykłady wpływu mediów

\begin{tabular}{|l|l|}
\hline \multicolumn{1}{|c|}{ Typ wpływu mediów } & \multicolumn{1}{|c|}{ Przykład zjawiska } \\
\hline $\begin{array}{l}\text { Wpływ społeczny widoczny } \\
\text { w zachowaniu }\end{array}$ & Rozhamowanie \\
\hline $\begin{array}{l}\text { Wpływ poznawczo-behawio- } \\
\text { ralny }\end{array}$ & $\begin{array}{l}\text { Dezinformacja w mediach wpływa na postawy i za- } \\
\text { chowania oraz poznawcze reprezentacje zjawisk }\end{array}$ \\
\hline Wpływ neurobiologiczny & $\begin{array}{l}\text { Stymulowanie lub brak takiej stymulacji aktywizu- } \\
\text { je lub dezaktywizuje konkretne struktury w mó- } \\
\text { zgu; wpływa na stan obwodów funkcjonalnych } \\
\text { odpowiadających za określone procesy poznawcze } \\
\text { i językowo-komunikacyjne }\end{array}$ \\
\hline
\end{tabular}

Źródło: opracowanie własne

Wyróżnione efekty można także analizować na trzech głównych poziomach: makro - czyli przez pryzmat zjawisk charakterystycznych dla współczesnej cywilizacji medialnej; mezo - w kontekście procesów i fenomenów, określających konkretną grupę użytkowników mediów, i mikro - w odniesieniu do czynników wewnętrznych i zewnętrznych warunkujących funkcjonowanie konkretnej jednostki.

2 A. Ogonowska, Psychologia mediów i komunikowania. Wprowadzenie, Oficyna Wydawnicza "Impuls”, Kraków 2018; J. Suler, Psychology of the digital age, Cambridge University Press, Cambridge 2016.

${ }^{3}$ M. Spitzer, Jak uczy się mózg?, Wydawnictwo Naukowe PWN, Warszawa 2011. 
Tabela 3. Trzy poziomy analizy wpływu mediów na człowieka i powiązane z nimi zjawiska

\begin{tabular}{|l|l|}
\hline Poziom analizy & \multicolumn{1}{|c|}{ Przykładowe zjawiska } \\
\hline Poziom makro & $\begin{array}{l}\text { Globalizacja, post-prawda, sfingowane informacje (ang. fake } \\
\text { news); hybrydyczne gatunki i formaty medialne; media jako } \\
\text { posttradycyjne instytucje edukacji }\end{array}$ \\
\hline Poziom mezo & $\begin{array}{l}\text { Bańki informacyjne charakterystyczne dla współczesnych } \\
\text { wspólnot dyskursywnych, pozorna dywersyfikacja źródeł } \\
\text { informacji; udział grup w tradycyjnych i nieformalnych typach } \\
\text { edukacji online i offline }\end{array}$ \\
\hline Poziom mikro & $\begin{array}{l}\text { Preferowane media. Style poznawcze, formy komunikacji; } \\
\text { wpływ najbliższego środowiska na kompetencje medialne, } \\
\text { cyfrowe, informacyjne jednostki }\end{array}$ \\
\hline
\end{tabular}

Źródło: opracowanie własne

W tym ostatnim kontekście (idiograficznym), warto jednocześnie zauważyć, iż w cyberpsychologii badamy relacje człowieka z mediami w różnych paradygmatach: medycznym (biologicznym), filozoficznym (antropologicznym), poznawczym (kognitywnym), rozwojowym oraz na ich przecięciu. Nie sposób również uniknąć odniesień do badań medioznawczych, pedagogicznych czy komunikologicznych, a nawet logopedycznych. Bardzo popularne, zwłaszcza w badaniach zachodnich i krajowych, jest podejście poznawczo-rozwojowe czy neurobiologiczno-edukacyjne, głównie w odniesieniu do dzieci i młodzieży szkolnej

${ }^{4}$ J. Cieszyńska-Rożek, Wpływ wysokich technologii na rozwój poznawczy dzieci $w$ wieku niemowlęcym i poniemowlęcym, [w:] Człowiek-Technologia-Media. Konteksty kulturowe i psychologiczne, red. A. Ogonowska, G. Ptaszek, Oficyna Wydawnicza „Impuls”, Kraków 2014, s. 11-22; J. Juszczyk-Rygałło, Nowe media a kształt wczesnej edukacji, [w:] Człowiek-Technologia-Media. Konteksty kulturowe i psychologiczne, red. A. Ogonowska, G. Ptaszek, Oficyna Wydawnicza „Impuls”, Kraków 2014, s. 51-62; A. Rygałło, Czy szkoła może być cyfrowa?, [w:] Człowiek-Technologia-Media. Konteksty kulturowe i psychologiczne, red. A. Ogonowska, G. Ptaszek, Oficyna Wydawnicza „Impuls”, Kraków 2014, s. 23-35. 
Interfejsy różnych technologii nie tylko pośredniczą w kontaktach społecznych, ale rzeczywistość wirtualna staje się często jedyną "przestrzenią społecznego kontaktu", nawet w takich obszarach, które pierwotnie bazowały na bezpośredniej interakcji: leczeniu, diagnozie, kształceniu czy udzielaniu wsparcia duchowego ${ }^{5}$. E-usługi współegzystują ze swoimi tradycyjnymi odpowiednikami, ale efektywne $\mathrm{z}$ nich korzystanie wymaga dynamicznego rozwoju społeczeństwa demokracji komunikacyjnej ${ }^{6}$ oraz minimalizowanie skali cyfrowego wykluczenia ${ }^{7}$. Badania przeprowadzone w 2014 r. pokazują, iż liczba osób dotkniętych tym zjawiskiem w Polsce sięga $12 \mathrm{mln}^{8}$.

Technologia staje się także integralnym elementem ludzkiego ciała, a wspomagając biologiczne funkcjonowanie organizmu, zarazem monitoruje jego funkcje, poziom sprawności i parametry psychofizjologiczne. Na podstawie tych informacji podmioty zewnętrzne i instytucje podejmują decyzję w sprawie rozwoju, życia, pracy i wielu instytucjonalnych świadczeń, związanych z jednostką "scyborgizowaną". Skrajnie negatywne efekty tego wpływu zostały sportretowane w brytyjskim serialu "Black Mirror" ${ }^{\prime \prime}$ oraz w polskim jego „odpowiedniku”, znanym jako „Czarne lustro”.

${ }^{5}$ A. Pasikowska, Dialog z wirtualnym i wyobrażonym rozmówca jako forma wsparcia i poprawy zdrowia psychicznego, [w:] Wspótczesna psychologia mediów. Nowe problemy i perspektywy badawcze, red. A. Ogonowska, G. Ptaszek, Oficyna Wydawnicza „Impuls", Kraków 2013, s. 231-248; J. Zając, Własne dobro czy prawdziwa pomoc? Przykłady nowych form zachowań pomocnych za pośrednictwem, [w:] Współczesna psychologia mediów. Nowe problemy i perspektywy badawcze, red. A. Ogonowska, G. Ptaszek, Oficyna Wydawnicza „Impuls”, Kraków 2013, s. 211-230.

${ }^{6}$ A. Ogonowska Edukacja medialna. Klucz do rozumienia społecznej rzeczywistości, Towarzystwo Naukowe: Societas Vistulana, Kraków 2003.

7 D. Batorski, Korzystanie z technologii informacyjno-komunikacyjnych, [w:] Diagnoza Społeczna 2009: Warunki i jakość życia Polaków, red. J. Czapiński, T. Panek, Vizja Press\&IT, Warszawa 2009, s. 281-309.

8 J. Jasiewicz, M. Filiciak, A. Mierzecka, K. Śliwowski, A. Klimczuk, M. Kisilowska, A. Tarkowski, J. Zadrożny, Katalog Kompetencji Cyfrowych, https://cppc.gov.pl/ wp-content/uploads/zal.-13-Ramowy_katalog_kompetencji_cyfrowych.pdf [dostęp: 25.12.2018].

${ }^{9} \mathrm{G}$. Wójcik, Rzeczywistość nie istnieje...? Media i nowoczesne technologie w społeczeństwie przyszłości na przykładzie serialu „Black Mirror”, „Studia de Cultura” 2016, nr VIII (2), s. 27-36. 
"Organiczny", "cielesny" kontekst dla mediów cyfrowych tworzy również sztuka nowych mediów "skonfigurowana" z body artem. Te nowe zastosowania medyczne i artystyczne zmieniają społeczny stosunek do nowych technologii oraz ich obecności w życiu człowieka. Media, także w sensie bardzo materialnym, redefiniują nasz stosunek do tożsamości, autonomii czy wolności ${ }^{10}$. Istotnym wymiarem nowych kompetencji medialnych jest $\mathrm{w}$ tym kontekście także wypracowanie nawyku ustawicznego namysłu nad miejscem mediów w naszym życiu (antropocentryczne ich "pozycjonowanie”).

Jednocześnie zmienia się stosunek ludzi do wytworów różnych technologii: $\mathrm{z}$ czysto przedmiotowego $\mathrm{i}$ instrumentalnego $\mathrm{w}$ podmiotowy i nacechowany humanistycznie ${ }^{11}$. Technologie wywołują u człowieka postawę empatii, współczucia, zaangażowania, często mimo świadomej deklaracji, iż reprezentują one porządek rzeczy, a nie natury (świata ożywionego). Umysł ludzi poszukuje $w$ humaniodalnych designach odpowiednika ludzkiego gatunku, z którym można nawiązywać nie tylko kontakt rzeczowy i celowy, ale także zawiązywać przymierze intelektualne, moralne i uczuciowe. Wymiar afektywny staje się nową przestrzenią relacji człowiek - technologia; człowiek - komputer; człowiek - interfejs ${ }^{12}$.

Zmiany te mają niebagatelny wpływ na strategie i formy kształcenia $\mathrm{W}$ społeczeństwie digitalnym. $\mathrm{W}$ coraz większym stopniu wykorzystuje się tzw. przyjazne interfejsy, sztuczną inteligencję oraz humanoidalne roboty ${ }^{13}$. Język nowych mediów staje się pod-

10 J. Suler, Psychology of the digital age, Cambridge University Press, Cambridge 2016; I. Connolly, Self and identity in cyberspace, [in:] An introduction to cyberpsychology, ed. I. Connolly, M. Palmer, H. Barton, G. Kirwan, Routledge, London - New York 2016, s. 45-56; U. Woźniak, Tożsamość w narracjach internetowych, "Studia de Cultura" 2016, nr VIII (2), s. 71-84.

11 B. Reeves, C. Nass, Media i ludzie, Państwowy Instytut Wydawniczy, Warszawa 2000.

12 A. Errity, Human-Computer Interaction, [in:] An introduction to cyberpsychology, ed. I. Connolly, M. Palmer, H. Barton, G. Kirwan, Routledge, London - New York 2016, s. 241-256.

13 A. Errity, op. cit., s. 271-285. 
stawowym kodem komunikowania społecznego, w przestrzeniach medialnych (i wirtualnych) oraz poza nimi.

Poważnym problemem dla rozwoju osobistego oraz zagrożeniem dla budowy społeczeństwa obywatelskiego jest narastająca liczba dezinformacji $\mathrm{w}$ mediach tradycyjnych i nowych mediach, które stają się podstawą podejmowania decyzji politycznych i konsumpcyjnych ${ }^{14}$. Szybkiemu dostępowi do różnych treści medialnych oraz do narzędzi służących produkcji różnych obiektów medialnych nie towarzyszy wzrost kompetencji informacyjnych, medialnych, cyfrowych. Użytkownicy na różnym poziomie rozumieją i posługują się aktywnie tym nowym językiem mediów.

Proponowane rozwiązania edukacyjne (edukacja formalna, nieformalna, kształcenie ustawiczne) nie spełniają jak dotąd pożądanych celów, gdyż nie są one dostosowane do potrzeb i możliwości (poznawczych, rozwojowych) poszczególnych grup docelowych. Potencjalni beneficjenci takich usług nie są także systemowo zmotywowani do podnoszenia swoich kompetencji medialnych, informacyjnych i cyfrowych; często nie dostrzegają oni związku między nimi a jakością własnego życia i codziennego funkcjonowania.

Poza tym o konieczności podnoszenia tychże umiejętności, wiedzy i kompetencji powinno się mówić językiem korzyści, a nie konieczności czy nakazów, oraz wiązać tą sferę z różnymi wyzwaniami właśnie codziennego życia i pełnionymi przez konkretną jednostkę rolami społecznymi (rodzinnymi, obywatelskimi, zawodowymi itp.).

Dostępność do nowych technologii, czyli istnienie społeczeństwa zinformatyzowanego, nie oznacza, że ludzie mają motywację i gotowość, by z nich korzystać. Warto przyjrzeć się tym barierom, zwłaszcza że znaczna część z nich ma charakter mentalny.

Samowykluczenie się z procesu przyswajania wiedzy i kompetencji medialnych, cyfrowych, informacyjnych z kolei przekłada się na rozwój takiej sfery publicznej, w której społeczne poznanie i in-

14 https:/ / eur-lex.europa.eu/legal-content/PL/TXT/PDF/?uri=CELEX:52018DC 0236\&from=EN [dostęp: 25.06.2018]. 
dywidualne reprezentacje poznawcze rzeczywistości bazują na postprawdzie i sfingowanych informacjach. Ta dezinformacja oraz brak właściwych kompetencji determinują zjawisko cyfrowego wykluczenia, budują społeczeństwo nie-wiedzy, dalekie od standardów dojrzałej demokracji oraz postaw tolerancji i humanizmu.

Tymczasem ponowoczesne kompetencje medialne $\mathrm{w}$ XXI $\mathrm{w}$. powinny być sprofilowane do nowych technologii, które funkcjonują zarówno jako przestrzeń edukacyjna, jak i powszechnie dostępne repozytorium wiedzy oraz narzędzi kształcenia. Język nowych mediów oraz architektura sieci mapuje ludzkie myślenie o rzeczywistości oraz formy działania $w$ ramach cywilizacji medialnej. Dotyczy to zwłaszcza pokoleń, które urodziły się świecie nowej generacji mediów interaktywnych, wirtualnych, hipertekstualnych i konwergentnych ${ }^{15}$.

Współcześnie nowe media, które stanowią podstawę e-usług i zmedityzowanej komunikacji społecznej, bazują na tylko na wzro$\mathrm{ku}$, słuchu i dotyku osobno, lecz odwołują się do wszystkich zmysłów jednocześnie, by potęgować wrażenie immersji, teleobecności; uczynić złudzenie „bycia” i „działania” w wirtualnej przestrzeni na poziomie doświadczenia indywidualnego. Rzeczywistość wirtualna i rozszerzona, podobnie jak inne media oparte na przyjaznych interfejsach, zmieniają stosunek człowieka do samych technologii, które w wielu kontekstach sytuacyjnych stają się "przezroczyste”. Nie uświadamiając sobie ich obecności, nie poddajemy również refleksji ich rzeczywistego wpływu na formy informacji i strategie międzyludzkiej komunikacji.

Uczymy się lubić technologie, z którymi współpracujemy. Czujemy się zagubieni, gdy nagłą awaria pozbawi nas możliwości dostępu do zasobów czy możliwości kontaktu z innymi poprzez media społecznościowe. Doceniamy fakt, iż rozwiązania technologiczne są doskonale dopasowane do naszych potrzeb, dlatego coraz

15 L. Manovich, Jezyk nowych mediów, Wydawnictwa Akademickie i Profesjonalne, Warszawa 2006; H. Jenkins, Kultura konwergencji. Zderzenie starych i nowych mediów, Wydawnictwa Akademickie i Profesjonalne, Warszawa 2007. 
chętniej traktujemy je jako rozszerzenia naszego ciała i naszych możliwości społecznych czy poznawczych.

Z coraz większym zaufaniem podchodzimy również do różnych form cyborgizacji naszego ciała, którego istotą, jak wspomniano wcześniej, jest to, że technologia wspomaga i monitoruje nie tylko jego procesy (jak np. kardiowerter-defibrylator, ICD), ale także umożliwia naszą geolokalizację (jak podskórne chipy). Stajemy się stopniowo, ale w coraz większej skali organicznym trybem, zaledwie biologicznym, choć niepozbawionym inteligencji, ogniwem ogromnej technologicznej infrastruktury, zwanej cywilizacją medialną.

Technologia, wyposażona $\mathrm{w}$ mechanizmy samodoskonalące się, samouczące, staje się coraz samodzielniejsza, wyzwalając się stopniowo, ale i systematycznie spod kontroli człowieka. Inteligentne rozwiązania, oparte na sztucznej inteligencji oraz symulatorach mowy, pozwalają uzyskać efekt (złudzenie) pełnej humanoidyzacji mediów. Te ostatnie przestają być tylko pośrednikami w komunikacji społecznej, a stają się głównymi rozgrywającymi. Ich „racjonalność", wyzbyta ludzkiej afektywności czy poczucia moralności, pozwala im szybko podejmować decyzję w oparciu o ciągle rozwijające się algorytmy i dane. Sposób przetwarzania BIG Data niedostępny do ludzkiego umysłu - technologiom informacyjnym nie nastręcza zbyt dużo problemów. Uzyskujemy - dzięki ich niezwykłym mocom obliczeniowym - zestawy analiz w różnych konfiguracjach jednocześnie.

Zapamiętywanie i przetwarzanie danych przestało być szczytowym osiągnięciem ludzkiego umysłu. Przestaje nim być także mowa oraz umiejętność posługiwania się językiem symbolicznym. Rola komunikacji bezpośredniej ulega zmniejszaniu się na rzecz posługiwania się nowymi językami komputerowymi oraz rozumienia logiki i infoestetyki mediów. Technologia i te nowe języki informatyczne "kolonizują" przestrzeń i strategie ludzkiego myślenia o naszym własnym doświadczeniu społecznym i intrapsychicznym.

Uczenie się, postrzegane jako kluczowa aktywność życiowa człowieka, prowadzi nie tylko do obserwowalnych zmian $\mathrm{w}$ zachowaniu, ale także neurobiologicznych i neurochemicznych, obej- 
mujących funkcjonowanie CUN, i to już w skali 1-2 pokoleń. Dochodzi zatem do przemian w strukturze i budowie mózgu, które przekładają się na preferowane formy komunikacji społecznej16.

Uczenie się i nabywanie nowych kompetencji kluczowych w coraz mniejszym stopniu kojarzone jest $\mathrm{z}$ edukacją formalną. Internet i nowe media mobilne stają się nie tylko posttradycyjną instytucją edukacji, ale - obok mowy, pisma i druku - wyznaczają całkowicie nowy paradygmat komunikacji społecznej17. Wpływają w coraz większym stopniu na edukację formalną, by wymienić e-learning, edukację hybryduczną/mieszaną czy MOOCs (ang. Massive Open Online Courses). Na przykładzie tej ostatniej formy widać wyraźnie, jak kultura WEB 2.0/Web 3.0 determinuje formę kształcenia nowych generacji jej użytkowników i producentów treści. Jeśli zestawimy sobie idee xMOOCs i cMOOCs, zmiana paradygmatu w edukacji (z tradycyjnego w ponowoczesny) staje się jeszcze widoczniejsza. W tym drugim przypadku to uczący się decydują o celach kształcenia oraz formach edukacji, zaś nauczyciel organizuje sam proces i monitoruje jego efektywność.

Rozwój neuronauki, w sprzężeniu z cybernetyką, automatyką, robotyką, genetyką oraz badaniami nad sztuczną inteligencją, pozwolił zidentyfikować zasoby i procesy poznawcze niezbędne do rozwoju kompetencji cyfrowych, medialnych i informacyjnych. Najczytelniejszą i najbardziej przekonującą propozycją w tym obszarze jest taksonomia digitalna Blooma. Wyróżniono w niej sześć kluczowych aktywności, którym podporządkowane są m.in. konkretne operacje umysłowe. Całość uporządkowana jest na linii wyznaczanej przez dwa skrajne wymiary: „umiejętności intelektualne wyższego rzędu" (HOTS, ang. Higher Order Thinking Skills) oraz niższego rzędu (LOTS, ang. Lower Order Thinkin Skills).

16 T.H.D. Parsons, Cyberpsychology and the Brain, Cambridge University Press, Cambridge 2017.

17 M. Palmer, The Internet as an educational space, [in:] An introduction to cyberpsychology, red. I. Connolly, M. Palmer, H. Barton, G. Kirwan, Routledge, London New York 2016, s. 194-208. 


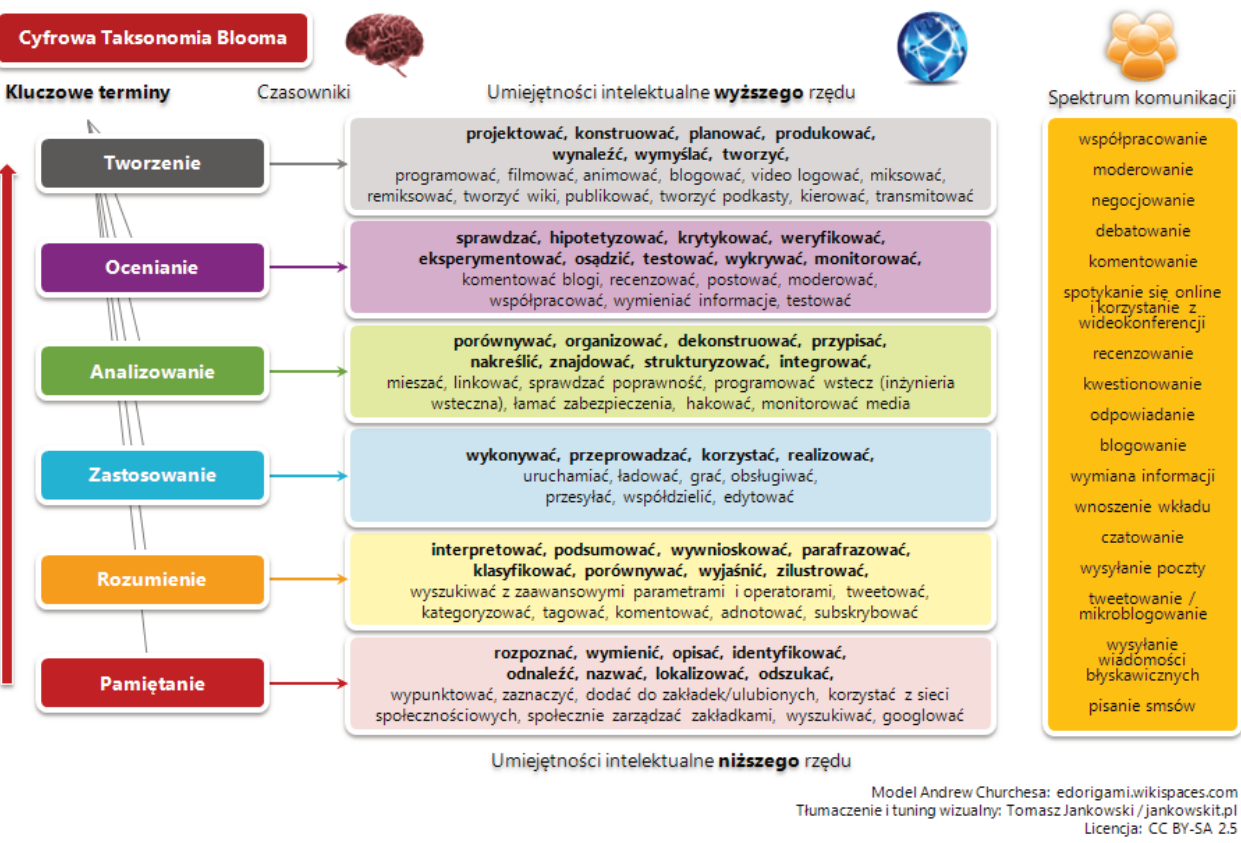

\section{W stronę dziecka}

Istotnym zadaniem współczesnych reformatorów edukacyjnych, którzy zajmują się praktyczną stroną edukacji medialnej, jest sprowadzenie wcześniejszych ustaleń związanych z diagnozą cywilizacyjną i opisem stanu mediów do pewnych konkretów. Warto rozważyć to zagadnienie $\mathrm{w}$ odniesieniu do najbardziej bezbronnego odbiorcy treści i użytkownika niektórych technologii, jakim jest dziecko. Jest to tym bardziej zasadne, iż wzrasta dynamicznie rynek produktów medialnych adresowanych do grupy wiekowej 2,5-7 lat, a wiele $\mathrm{z}$ nich posługuje się marketingowo sprawdzonym hasłem: "produktu edukacyjnego". W wielu przypadkach nie bierze się pod uwagę, przy ich projektowaniu, rzeczywistych możliwości poznawczych dziecka w tym wieku, nie wspominając o jego kompetencjach medialnych, cyfrowych i informacyjnych. 
Jeśli wykorzystać semiotyczne myślenie, każdy taki produkt powinien zawierać w sobie odbiorcę wirtualnego, implikowanego przez autora i realizatora określonej koncepcji medialnej (zarówno w postaci technologii, jak i przekazu medialnego). Aby zobaczyć, na ile występuje kompatybilność między możliwościami poznawczymi dziecka a wymaganiami stawianymi przez produkt, należy dokonać specyficznej analizy obu tych czynników. W odniesieniu do dziecka proponuję wykorzystać jedno z popularniejszych narzędzi stosowanych w diagnozie psychologicznej i logopedycznej.

Test SON-R $(2,5-7)^{18}$, o którym mowa, składa się z sześciu podtestów warunkujących uczenie się języka mówionego i pisanego. Umożliwia on przeprowadzenie diagnozy preferencji zadań prawopółkulowych i lewopółkulowych oraz obliczenie wieku rozwojowego dziecka dla każdej funkcji oraz ilorazu inteligencji. To narzędzie diagnostyczne, które pozwala obliczyć wiek umysłowy badanego dla pięciu funkcji psychicznych oraz iloraz inteligencji $\mathrm{w}$ grupie dzieci mówiących oraz $\mathrm{w}$ grupie dzieci $\mathrm{z}$ zaburzeniami komunikacji językowej. Badanie każdej sfery rozpoczyna się od zadań przeznaczonych dla dzieci dwuletnich, co daje możliwość sprawdzenia funkcjonowania dziecka od 24. miesiąca życia.

Test SON-R bada takie funkcje poznawcze, jak:

1) umiejętność dokonywania kategoryzacji,

2) analizę i syntezę wzrokową na materiale atematycznym (symbolicznym),

3) analizę i syntezę wzrokową na materiale tematycznym,

4) koncentrację i pamięć bezpośrednią,

5) grafopercepcję.

18 Test skierowany do dzieci od 2,5. do 7. roku życia. W praktyce diagnostyczne najczęściej jest on wykorzystywany do badania dzieci, u których rozwój mowy nie przebiega prawidłowo lub mających kłopoty w nauce czytania. Autorzy: SnijdersOomen, Peter Tellegen, Marjolijn Winkel, Barbara Wijnberg-Williams, Jaap Laros. Użytkownicy testu: psychologowie, logopedzi. Normy dla tekstu mają charakter międzynarodowy. 
Tabela 4. Funkcje poznawcze oraz powiązane z nimi umiejętności

\begin{tabular}{|l|l|}
\hline \multicolumn{1}{|c|}{$\begin{array}{c}\text { Funkcje } \\
\text { poznawcze }\end{array}$} & \multicolumn{1}{|c|}{ Szczegółowe umiejętności w odniesieniu do zadań } \\
\hline Kategoryzacja & $\begin{array}{l}\text { Przetwarzanie symultaniczne i sekwencyjne; aktywizacja działania obu } \\
\text { półkul mózgu; gotowość uczenia się pojęć językowych; umiejętność do- } \\
\text { strzegania podobieństw i różnic między obiektami; analogii; dokonywania } \\
\text { transferu wiedzy oraz strategii rozwiązywania zadań na nowy materiał }\end{array}$ \\
\hline $\begin{array}{l}\text { Analiza i synteza } \\
\text { wzrokowa (mate- } \\
\text { riał atematyczny) }\end{array}$ & $\begin{array}{l}\text { Sekwencyjne przetwarzanie i aktywizacja lewej półkuli mózgu; umiejęt- } \\
\text { noś linearnego porządkowania informacji i sekwencyjnego prezentowania } \\
\text { go; porządkowanie materiału od lewej do prawej, naśladowanie zacho- } \\
\text { wańlałań na konkretnych elementach }\end{array}$ \\
\hline $\begin{array}{l}\text { Analiza i synteza } \\
\text { wzrokowa (mate- } \\
\text { riał tematyczny) }\end{array}$ & $\begin{array}{l}\text { Przetwarzanie symultaniczne informacji i aktywizacja prawej półkuli; } \\
\text { określenie poziomu umiejętności naśladownictwa; koncentracji wzrokowo- } \\
\text { ruchowej; poziom syntezy różnorodnego materiału }\end{array}$ \\
\hline $\begin{array}{l}\text { Koncentracja i pa- } \\
\text { mięć bezpośred- } \\
\text { nia }\end{array}$ & $\begin{array}{l}\text { Sterowanie uwagą własną oraz koncentracja na zadaniu; rozumienie in- } \\
\text { strukcji pozawerbalnej; pamięć bezpośrednia, samodzielne poszukiwanie } \\
\text { sposobów rozwiązywania zadań }\end{array}$ \\
\hline Grafopercepcja & $\begin{array}{l}\text { Naśladowanie i współdziałanie, wykonywanie sekwencyjnych ruchów } \\
\text { precyzyjnych, aktywizacja lewej półkuli mózgu. Uzyskane wyniki pozwa- } \\
\text { lają określić gotowość do naśladowania mowy, koordynację wzrokowo- } \\
\text { ruchową; percepcję wzrokową, sprawność manualną }\end{array}$ \\
\hline
\end{tabular}

Opracowano na podstawie: http://www.testresearch.nl/sonr/sonr257manual.pdf [dostęp: 23.0618]

Wszystkie wymienione funkcje poznawcze odgrywają istotną rolę $\mathrm{w}$ rozumieniu i interpretacji przekazów medialnych. Początkowo (w wieku 2,5-4 lat) dziecko przykładowo identyfikuje ulubiony program, rozpoznaje bohaterów, potrafi (werbalnie i niewerbalnie) wyrażać wobec nich różne emocje i postawy. Do trzeciego roku życia młody odbiorca jest bardzo podatny na cechy formalne przekazów, np. dynamiczny montaż czy głośną muzykę. To właśnie te bodźce (audio)wizualne wywołują $u$ niego odruch orientacyjny. Koncentrując swoją uwagę na wyrazistych elementach komunikatu, dziecko ma problem $w$ bardziej analitycznym rozumieniem jego treści, zwłaszcza że przekaz nieustannie się zmienia na ekranie. Rolą opiekuna jest stopniowe budowanie i rozwijanie tej umiejętno- 
ści poprzez wspólną analizę poszczególnych fragmentów przekazu i, o ile jest to możliwe, nawiązywanie do pozamedialnych doświadczeń dziecka. W ten sposób uczy się ono, iż świat medialny w jakimś fragmencie jest reprezentacją świata rzeczywistego. W umyśle dziecka tworzy się stopniowo idea reprezentacji. Dzięki rozmowom medialnym $\mathrm{z}$ dorosłymi, odbiorca $\mathrm{w}$ tym wieku uczy się także dostrzegać różnice i podobieństwa pomiędzy różnymi przekazami; zaczyna również dostrzegać je między różnymi mediami (np. bajką w książeczce i bajką filmową).

W wieku 4-6 lat dziecko stopniowo uczy się rozpoznawać schematy gatunkowe, rozumie związki przyczynowo-skutkowe, identyfikuje relacje między bohaterami. Potrafi także intuicyjnie i z wykorzystaniem doświadczenia medialnego przewidywać rozwój akcji (5,5-7. rok życia). Dziecko w tym wieku odtwarza także w formie zabaw tematycznych lub symbolicznych te sekwencje z filmów czy bajek, które najbardziej utkwiły mu w pamięci, także z uwagi na swój "ciężar emocjonalny”, zarówno pozytywny, jak i negatywny. Dziecko powyżej 6. roku życia rozwija stopniowo umiejętność decentracji poznawczej, co umożliwia mu spojrzenie na rzeczywistość medialną "oczami innej postaci”.

Bezpośrednie interakcje ( $\mathrm{w}$ przestrzeni offline) umożliwiają także naśladowanie zachowań medialnych opiekunów, którzy na tym etapie rozwoju dzieci powinni aktywnie pośredniczyć $w$ tych kontaktach (jako modele pożądanych zachowań, inicjatorzy różnych aktywności medialnych oraz „tłumacze" rzeczywistości online). Psychologowie w tym kontekście piszą o różnych rodzajach i funkcjach mediacji ${ }^{19}$. Reasumując, rozwój kompetencji medialnych dziecka w odniesieniu do przekazów o charakterze audiowizualnym przebiega do siódmego roku życia według następujących etapów:

- poziom reakcji orientacyjnych,

- poziom wyodrębniania z przekazu poszczególnych elementów znaczących (np. przedmiotów, postaci),

19 A. Kołodziejczyk, Media w życiu rodziny. Rodzaje mediacji korzystania z mediów, [w:] Wspótczesna psychologia mediów. Nowe problemy i perspektywy badawcze, red. A. Ogonowska, G. Ptaszek, Oficyna Wydawnicza „Impuls”, Kraków 2013, s. 49-70. 
- poziom łączenia elementów w większe całości znaczące (np. zgodnie z zasadą ich formalnego podobieństwa),

- poziom rozumienia relacji między elementami oraz prostych narracji (np. opartych na związkach przyczynowo-skutkowych lub przynależności do określonego zbioru obiektów - kategoryzacja),

- poziom odtwarzania niektórych medialnych sytuacji lub naśladowania zachowań medialnych bohaterów w zabawie (najpierw indywidualnie, potem we współpracy z innymi dziećmi),

- poziom rozumienia idei reprezentacji, tzn. związku między fragmentem przekazu a fragmentem rzeczywistości zewnętrznej,

- poziom identyfikowania różnic i podobieństw (formalnych, treściowych) między różnymi przekazami,

- poziom świadomego zarządzania uwagą i aktywna koncentracja na różnych elementach przekazu, w tym na kontekście społecznym, w którym działają bohaterowie,

- poziom umiejętności stosowania wskazówek/instrukcji z przekazu do działania w realnym środowisku,

- poziom przewidywania rozwoju akcji na podstawie wcześniejszego doświadczenia medialnego.

Jak widać z tego syntetycznego opisu, kompetencje medialne rozwijają się na bazie różnych funkcji poznawczych. Nie jest to jednak proces automatyczny. Wymaga ogromnego zaangażowania ze strony opiekunów, których zadaniem jest kształtowanie od samego początku właściwych postaw i zachowań wobec mediów. Domowa edukacja medialna staje się podstawą pożądanych aktywności medialnych, które sprzyjają m.in. rozwojowi krytycznego myślenia i umiejętności radzenia sobie z dezinformacją na kolejnych etapach rozwoju.

\section{Bibliografia}

Batorski D., Korzystanie z technologii informacyjno-komunikacyjnych, [w:] Diagnoza Społeczna 2009: Warunki i jakość życia Polaków, red. J. Czapiński, T. Panek, Vizja Press\&IT, Warszawa 2009, s. 281-309. 
Cieszyńska-Rożek J., Wptyw wysokich technologii na rozwój poznawczy dzieci w wieku niemowlęcym i poniemowlęcym, [w:] Cztowiek-Technologia-Media. Konteksty kulturowe i psychologiczne, red. A. Ogonowska, G. Ptaszek, Oficyna Wydawnicza „Impuls", Kraków 2014, s. 11-22.

Connolly I., Self and identity in cyberspace, [in:] An introduction to cyberpsychology, ed. I. Connolly, M. Palmer, H. Barton, G. Kirwan, Routledge, London - New York 2016, s. 45-56.

Errity A., Human-Computer Interaction, [in:] An introduction to cyberpsychology, ed. I. Connolly, M. Palmer, H. Barton, G. Kirwan, Routledge, London - New York 2016, s. 241- 256.

Jasiewicz J., Filiciak M., Mierzecka A., Śliwowski K., Klimczuk A., Kisilowska M., Tarkowski A., Zadrożny J., Katalog Kompetencji Cyfrowych, https://cppc.gov. pl/wp-content/uploads/zal.-13-Ramowy_katalog_kompetencji_cyfrowych.pdf [dostęp: 25.12.2018].

Jenkins H., Kultura konwergencji. Zderzenie starych i nowych mediów, Wydawnictwa Akademickie i Profesjonalne, Warszawa 2007.

Juszczyk-Rygałło J., Nowe media a kształt wczesnej edukacji, [w:] Człowiek-TechnologiaMedia. Konteksty kulturowe i psychologiczne, red. A. Ogonowska, G. Ptaszek, Oficyna Wydawnicza “Impuls”, Kraków 2014, s. 51-62.

Kirwan G., Psychological applications of Virtual Reality, [in:] An introduction to cyberpsychology, ed. I. Connolly, M. Palmer, H. Barton, G. Kirwan, Routledge, London - New York 2016, s. 271-285.

Kołodziejczyk A., Media w życiu rodziny. Rodzaje mediacji korzystania z mediów, [w:] Wspótczesna psychologia mediów. Nowe problemy i perspektywy badawcze, red. A. Ogonowska, G. Ptaszek, Oficyna Wydawnicza „Impuls”, Kraków 2013, s. 49-70.

Manovich L., Jezyk nowych mediów, Wydawnictwa Akademickie i Profesjonalne, Warszawa 2006.

Ogonowska A., Edukacja medialna. Klucz do rozumienia społecznej rzeczywistości, Towarzystwo Naukowe: Societas Vistulana, Kraków 2003.

Ogonowska A., Kompetencje cyfrowe we wspótczesnej cywilizacji medialnej, „Studia de Cultura" 2016, nr VIII (2), s. 14-26.

Ogonowska A., Psychologia mediów i komunikowania. Wprowadzenie, Oficyna Wydawnicza „Impuls”, Kraków 2018.

Ogonowska A., Wspótczesna edukacja medialna: teoria i rzeczywistość, Wydawnictwo Naukowe Uniwersytetu Pedagogicznego, Kraków 2013.

Parsons T. H. D., Cyberpsychology and the Brain, Cambridge University Press, Cambridge 2017.

Palmer M., The Internet as an educational space, [in:] An introduction to cyberpsychology, ed. I. Connolly, M. Palmer, H. Barton, G. Kirwan, Routledge, London - New York 2016, s. 194-208.

Pasikowska A., Dialog $z$ wirtualnym $i$ wyobrażonym rozmówca jako forma wsparcia i poprawy zdrowia psychicznego, [w:] Wspótczesna psychologia mediów. Nowe prob- 
lemy i perspektywy badawcze, red. A. Ogonowska, G. Ptaszek, Oficyna Wydawnicza „Impuls”, Kraków 2013, s. 231-248.

Reeves B., Nass C., Media i ludzie, Państwowy Instytut Wydawniczy, Warszawa 2000.

Rygałło A., Czy szkoła może być cyfrowa?, [w:] Człowiek-Technologia-Media. Konteksty kulturowe i psychologiczne, red. A. Ogonowska, G. Ptaszek, Oficyna Wydawnicza „Impuls”, Kraków 2014, s. 23-35.

Spitzer M., Jak uczy się mózg?, Wydawnictwo Naukowe PWN, Warszawa 2011.

Suler J., Psychology of the digital age, Cambridge University Press, Cambridge 2016.

Woźniak U., Tożsamość w narracjach internetowych, „Studia de Cultura” 2016, nr VIII (2), s. $71-84$.

Wójcik G., Rzeczywistość nie istnieje...? Media i nowoczesne technologie w społeczeństwie przyszłości na przykładzie serialu „Black Mirror", „Studia de Cultura” 2016, nr VIII (2), s. 27-36.

Zając J., Własne dobro czy prawdziwa pomoc? Przykłady nowych form zachowań pomocnych za pośrednictwem, [w:] Wspótczesna psychologia mediów. Nowe problemy i perspektywy badawcze, red. A. Ogonowska, G. Ptaszek, Oficyna Wydawnicza „Impuls", Kraków 2013, s. 211-230. 